\title{
TEORIA DO DESIGN
}

\author{
Maria Heloísa Moreira Marmo - helomarmo@gmail.com \\ Faculdades Oswaldo Cruz - Faiter - Desenho Industrial (habilitações em Programação \\ Visual e Projeto do Produto) \\ Curso anual até 2013, Curso semestral a partir de 2014
}

\section{a. Foco da disciplina / recorte temporal e geográfico}

Teoria do Design apresenta uma abordagem inicialmente da história internacional (Inglaterra e França) sobre questões das revoluções industriais e, no transcurso das aulas, tece as situações brasileiras a partir da chegada de Dom João VI, a criação do Liceu de Artes e Ofícios, tendo em vista reflexões sobre certos preconceitos entre arte, artesanato e design, no período. Prossegue com abordagens relativas ao Iac-Masp e as implementações dos cursos de Desenho Industrial da Fau-Usp e da Esdi,seguindo por várias discussões pertinente ao design. Discute, também, as características do ArtsandCrafts, do Art Nouveau, do Art Déco, para inserir a história do design a partir do século XX, relacionando as vária vertentes ocorridas no transcorrer do último século com as produções atuais.

Atualmente os cursos da Faiter estão com programação semestral e somente no $5^{\circ}$ semestre, portanto no início de 2015, é que a disciplina terá seu espaço.

Quando assumi ser professora de Teoria do Design (2007), o bacharelado de Desenho Industrial da Faiter apresentava um programa anual e a disciplina era oferecida nos dois primeiros anos. Em 2013 houve uma alteração da grade curricular, passando de $160 \mathrm{~h}$ para $80 \mathrm{~h}$, sendo oferecida apenas no $1^{\circ}$ ano. Neste ano de 2014 a estrutura do curso mudou de anual para semestral e o desafio será adaptar o horário de $80 \mathrm{~h}$ para 40 hcorrespondentes às abordagens da matéria.

\section{b. Abordagem temática da disciplina}

Apresentar uma contextualização socioeconômica entrelaçada com aspectos éticos e estéticos, tendo em vista possibilitar a identificação do campo de atuação do designer, 
compreendendo o atual processo de transformação em sua abrangência histórica. A ementa de Teoria do Design no programa anual é " a disciplina capacita o estudante a conhecer a História e a Teoria do Design desde as revoluções industriais até os dias atuais, as alterações de períodos, seus diferentes estilos, materiais e procedimentos, por meio de reflexões sobre tendências e aspectos atuais do design." e a relação do conteúdo programático discorre sobre

. etimologia, conceitos e introduções sobre design

. artesanato, desenho industrial e o conceito de standart

. categorias de objetos: produtos artesanais e produtos industriais

. funções dos produtos industriais: prática, estética e simbólica

. aspectos que definem o design gráfico

. áreas de atuação do designer em projeto de produto e programação visual

. as revoluções industriais: do artesanato à arte industrial

. cenário urbano do século XIX

. design e reformismo social

. ArtsandCrafts e os ateliês de William Morris

. Art Nouveau e Art Déco

. conceito sociológico de massa

. aspectos nacionalistas e a Werkbundalemã

. design entre e pós guerras

. design e marketing

. conceito de kitsch

. design na contemporaneidade e reflexões sobreo que sentimos e vivemos

. design e meio ambiente

\section{c. Métodos pedagógicos e recursos avaliativos}

As aulas apresentam-se em formato expositivo com exemplificações e análises de referências sobre os assuntos abordados. Todos os conteúdos de aulas são publicados sinteticamente no site do professor do portal www.oswaldocruz.br, em páginas de conteúdos, em arquivos de imagem e todas as programações de aulas, trabalhos, questionários e provas são organizados em comunicados, além de notícias sobre eventos e exposições sobre design que são sugeridas no site. Também são apresentados documentários sobre design e filmes que exemplificam momentos históricos discutidos em aulas. Há, ainda, atividades desenvolvidas fora da sala de aula que envolvem leituras orientadas sobre textos bibliográficos para pesquisas para seminários. 
As avaliações correspondem a exercícios integrados (teste com quatro alternativas) com as demais disciplinas do curso; trabalhos práticos (seminários em equipe com abordagens específicas e sugestões para pesquisas sobre os temas sorteados para as apresentações) e questionários reflexivos onde, através de perguntas formuladas previamente, os alunos pesquisam e consultam as bibliografias para suas respostas.

\section{d. Papel da disciplina no curso}

O papel da Teoria do Design na formação do curso é situar o surgimento do Desenho Industrial em meio às transformações desencadeadas pelas revoluções industrias, sensibilizar para os estilos decorrentes de uma estética industrial, além de possibilitar reflexões sobre o desenvolvimento urbano a partir do início do século XX até nossos dias e qual a relevânciado designer na sociedade.

\section{e. Percepção dos alunos quanto à disciplina}

Os alunos avaliam a disciplina positivamente, percebendo-a como um recurso de conhecimento teórico necessário para suas aplicações práticas, uma vez que participam efetivamente das aulas, principalmente quando são feitos paralelos entre o que foi, o que está e como poderia ser, quando produzem seus seminários.

\section{f. Bibliografia para as aulas}

\section{Básica}

ARGAN, Giulio Carlo. Arte Moderna. São Paulo: Companhia das Letras, 2002

DENIS, Rafael Cardoso. Uma introdução à história do design. São Paulo: Edgard Blücher, 2000.

STRUNK, Gilberto. Viver de design. Rio de Janeiro: 2AB, 1999.

\section{Complementar}

BURDEK, Bernhard E. História, Teoria e Prática do Design de Produtos. Trad.: Freddy Van Camp. Edit. Edgard Blücher, São Paulo, 2006.

MORAES, Dijon de. Limites do Design. São Paulo: Estúdio Nobel, 2008.

PEVSNER, Nikolaus. Os pioneiros do desenho moderno: de William Morris a Walter. 2.ed. São Paulo: Martins Fontes1995. 